\title{
Plant Architecture and Flag Leaf Morphology of Rice Crops Exposed to Experimental Warming with Elevated $\mathrm{CO}_{2}$
}

\author{
Thang $\mathrm{Vu}^{*}$ and Han-Yong $\mathrm{Kim}^{*} *^{\dagger}$ \\ *Department of Crop Production, National Center for Plant and Fertilizer Testing, 6 Nguyen Cong Tru street, Hai Ba \\ Trung district, Hanoi, Vietnam. \\ **Department of Applied Plant Science, Chonnam National University, 77 Yongbong-ro, Buk-gu, Gwangju 500-757, Korea.
}

\begin{abstract}
Projected increases in atmospheric $\mathrm{CO}_{2}$ concentration $\left(\left[\mathrm{CO}_{2}\right]\right)$ and temperature $\left(\mathrm{T}_{\mathrm{a}}\right)$ have the potential to alter in rice growth and yield. However, little is known about whether $\mathrm{T}_{a}$ warming with elevated $\left[\mathrm{CO}_{2}\right]$ modify plant architecture. To better understand the vertical profiles of leaf area index (LAI) and the flag leaf morphology of rice grown under elevated $\mathrm{T}_{\mathrm{a}}$ and $\left[\mathrm{CO}_{2}\right]$, we conducted a temperature gradient field chamber (TGC) experiment at Gwangju, Korea. Rice (Oryza sativa L. cv. Dongjin1ho) was grown at two $\left[\mathrm{CO}_{2}\right][386$ (ambient) vs $592 \mathrm{ppmV}$ (elevated)] and three $\mathrm{T}_{\mathrm{a}}$ regimes [26.8 ( $\approx$ ambient $), 28.1$ and $29.8^{\circ} \mathrm{C}$ ] in six independent field TGCs. While elevated $\mathrm{T}_{\mathrm{a}}$ did not alter total LAI, elevated $\left[\mathrm{CO}_{2}\right]$ tended to reduce (c. $6.6 \%$ ) the LAI. At a given canopy layer, the LAI was affected neither by elevated $\left[\mathrm{CO}_{2}\right]$ nor by elevated $\mathrm{T}_{\mathrm{a}}$, allocating the largest LAI in the middle part of the canopy. However, the fraction of LAI distributed in a higher and in a lower layer was strongly affected by elevated $\mathrm{T}_{\mathrm{a}}$; on average, the LAI distributed in the 75-90 $\mathrm{cm}$ (and 45-60 $\mathrm{cm}$ ) layer of total LAI was $9.4 \%$ (and 35.0\%), $18.8 \%$ $(25.9 \%)$ and $18.6 \%(29.2 \%)$ in ambient $\mathrm{T}_{\mathrm{a}}, 1.3^{\circ} \mathrm{C}$ and 3. $0^{\circ} \mathrm{C}$ above ambient $\mathrm{T}_{\mathrm{a}}$, respectively. Most of the parameters related to flag leaf morphology was negated with elevated $\left[\mathrm{CO}_{2}\right]$; there were about $12 \%, 5 \%, 7.5 \%, 15 \%$ and $21 \%$ decreases in length $(\mathrm{L})$, width $(\mathrm{W}), \mathrm{L}: \mathrm{W}$ ratio, area and mass of the flag leaf, respectively, at elevated $\left[\mathrm{CO}_{2}\right]$. However, the negative effect of elevated $\left[\mathrm{CO}_{2}\right]$ was offset to some extent by $\mathrm{T}_{\mathrm{a}}$ warming. All modifications observed were directly or indirectly associated with either stimulated leaf expansion or crop phenology under $\mathrm{T}_{\mathrm{a}}$ warming with elevated $\left[\mathrm{CO}_{2}\right]$. We conclude that plant architecture and flag leaf morphology of rice can be modified both by $T_{a}$ warming and elevated $\left[\mathrm{CO}_{2}\right]$ via altering crop phenology and the extent of leaf expansion.
\end{abstract}

Keywords : plant architecture, leaf morphology, elevated $\mathrm{CO}_{2}$, global warming, rice

There are obvious concerns about the impact of a projected increase in atmospheric $\mathrm{CO}_{2}$ concentration $\left(\left[\mathrm{CO}_{2}\right]\right)$ and temperature $\left(\mathrm{T}_{\mathrm{a}}\right)$ on agricultural field crop species. Many studies highlighted that elevated $\left[\mathrm{CO}_{2}\right]$ (i.e. 200-300 ppmV above current ambient $\left[\mathrm{CO}_{2}\right]$ ) increases yield of major $\mathrm{C}_{3}$ cereal crops such as rice, wheat and so on (see reviews by Ainsworth and Long, 2005; Ziska and Bunce, 2007). However, far less attention has been paid to whether a projected increase in $\left[\mathrm{CO}_{2}\right]$ and $\mathrm{T}_{\mathrm{a}}$ will modify plant architecture and morphology, which play critical role in plant photosynthesis and hence in crop yield. In a recent review, it is becoming more evident that an ideal plant type of rice is necessary to break current stagnation of the yield (Peng et al., 2008). This concept will also be just the case for the future high $\left[\mathrm{CO}_{2}\right]$ world to take full advantage of the high $\left[\mathrm{CO}_{2}\right]$ into the yield increase, and to minimize a disadvantage of $T_{a}$ warming. In this context, understanding of the plant architecture and morphology of rice crops grown under elevated $\left[\mathrm{CO}_{2}\right]$ and $\mathrm{T}_{\mathrm{a}}$ is the first step to develop an effective plant type of rice which is highly adaptable to projected climate change.

Plant architecture of rice is defined as three-dimensional distribution of plant component parts, such as plant height, tiller and leaf area. Since these all traits determine the potential yield of rice, plant architecture has been recognized as a major agronomic importance (Khush, 2001; Peng et al., 2008; Ariyaratna et al., 2011). The architecture of rice

\footnotetext{
Corresponding author: (Phone) +82-62-530-2051 (E-mail) hyk1020@chonnam.ac.kr
}

$<$ Received 1 August 2011; Revised 27 August 2011; Accepted 31 August 2011> 
plants can be affected by several environmental factors (e.g. $\mathrm{T}_{\mathrm{a}},\left[\mathrm{CO}_{2}\right]$ ), as well as by genetic backgrounds. For example, elevated $\left[\mathrm{CO}_{2}\right]$ had little affect plant height of inbred rice (cv. Akihikari) (Kim et al., 1996), but strong positive affect that of hybrid rice (cv. Liangyoupeijiu) (Yang et al., 2009). However, $T_{a}$ warming universally appears to have a stimulatory effect on plant height of rice plants (Oh-e et al., 2007). Early studies reported that although elevated $\left[\mathrm{CO}_{2}\right]$ increases tiller number of rice crops, this stimulatory effect is only significant up to heading but a relatively minor afterward (Kim et al., 2003). A similar response fashion to elevated $\left[\mathrm{CO}_{2}\right]$ was also reported for leaf area of rice plants (Kim et al., 2003; Sakai et al., 2006). Such changes in plant height, tiller and leaf area under elevated $\left[\mathrm{CO}_{2}\right]$ and/or $\mathrm{T}_{\mathrm{a}}$ will have the potential to modify in plant architecture at whole-plant or canopy level. However, there are no reports addressing the vertical profiles of leaf area of rice crops exposed to elevated $\left[\mathrm{CO}_{2}\right]$ and $\mathrm{T}_{\mathrm{a}}$. In addition to plant height and tiller, the vertical profiles of leaf area are key factors for integrating and understanding the plant architecture at whole-plant level. Hence, it remains to be determined whether a projected warming with elevated $\left[\mathrm{CO}_{2}\right]$ alters vertical profiles of leaf area of rice crops in order to better understand plant architecture at whole-pant level.

Unlike wheat and barley, which have a greater capability of ear photosynthesis (Evan and Rawson, 1969; Zhu et al., 2008), in rice the flag leaves play a crucial role in plant photosynthesis during grain filling period, thus determining grain yield. For example, rice flag leaves at heading stage contribute about $19 \%$ of total leaf area (Yoshida et al., 1972), and contribute about $45 \%$ of total grain yield (Abou-khalifa et al., 2008). To date, however, it has rarely been reported for the morphology of the flag leaf in rice crops grown under expected warming with elevated $\left[\mathrm{CO}_{2}\right]$. To better understand the changes that occur in plant architecture under changes in $\left[\mathrm{CO}_{2}\right]$ and climate, it is needed to consider not only the vertical profiles of leaf area, but also the flag leaf morphology.

In the present study, we examined whether elevated $T_{a}$ in combination with elevated $\left[\mathrm{CO}_{2}\right]$ would affect plant architecture of rice crops by employing temperature gradient field chambers (TGCs). The objectives of this study were; (i) to determine the vertical profiles of leaf area of rice crops under elevated $\mathrm{T}_{\mathrm{a}}$ and $\left[\mathrm{CO}_{2}\right]$; (ii) to identify the changes in the effect of elevated $\left[\mathrm{CO}_{2}\right]$ and $\mathrm{T}_{\mathrm{a}}$ on flag leaf morphology of rice crops.

\section{MATERIALS AND METHODS}

\section{Experimental site and system descriptions}

The experimental site was located in the experimental paddy fields of Chonnam National University, Gwangju, Korea $\left(126^{\circ} 53^{\prime} \mathrm{E}, 35^{\circ} 10^{\prime} \mathrm{N}\right.$, alt. $\left.33 \mathrm{~m}\right)$. The area is typical of the agro-climate that grows a large proportion of Korean rice crops, occupying $>20 \%$ of total area harvested (approximately one million ha). This site was subject to temperate monsoon climate with an annual mean temperature of $13.7^{\circ} \mathrm{C}$ over the past 30 years. Annual mean precipitation was about $1520 \mathrm{~mm}$, with $>60 \%$ rainfall occurring from June to August (rainy season). During the rice growing season (May to September), the mean $T_{a}$ was $22.7^{\circ} \mathrm{C}$, with a monthly mean minimum and maximum $T_{a}$ of $12.8^{\circ} \mathrm{C}$ (May) and $30.5^{\circ} \mathrm{C}$ (August), respectively.

The experiment was performed using TGCs established in paddy fields, covered by a highly transparent film, with or without $\mathrm{CO}_{2}$ fumigation. TGCs have been described in detail by Kim et al. 2004 (also see Horie et al., 1995; Okada et al., 2000). Briefly, the TGCs consisted of six independent field chambers that had a tunnel shape of 24.0 $\mathrm{m}$ in length, $2.4 \mathrm{~m}$ in width and $2.0 \mathrm{~m}$ in height. Of these, three TGCs were allocated for ambient $\left[\mathrm{CO}_{2}\right]$ and the other three were allocated for elevated $\left[\mathrm{CO}_{2}\right]$. The target $\left[\mathrm{CO}_{2}\right]$ in the TGCs assigned to the elevated $\left[\mathrm{CO}_{2}\right]$ was $600 \mathrm{ppmV}$ and controlled by fumigating $\mathrm{CO}_{2}$ mixed with air in a mixing cylinder. One side of the TGC in the longitudinal direction was fully open (air inlet); while the other side (air outlet) was closed, where three exhaust fans [two small $\left(17.7 \mathrm{~m}^{3} \mathrm{~min}^{-1}\right)$ and one large $\left.\left(125.0 \mathrm{~m}^{3} \min ^{-1}\right)\right]$ were mounted. Air from the inlet traveled towards the outlet by the exhaust fans and was gradually warmed by either incident solar radiation (clear day) or warm air provided by an electronic heating blower at nighttime (including cloudy and rainy day), creating a linear $T_{a}$ gradient along the longitudinal axis of the TGCs. The $T_{a}$ difference between the air inlet ( ambient) and outlet of the TGC was set at 
$3^{\circ} \mathrm{C}$ with natural diurnal fluctuations. To minimize the enclosure effects expected, we used highly transparent films (F-clean ${ }^{\circledR}$, Asahi Glass, Japan) with a transmittance > $90 \%$ in a wide range of radiation from short- to long-wave. In addition, an oscillating fan was placed on one side wall inside the TGCs with $4.0 \mathrm{~m}$ distance intervals in order to disperse $\mathrm{CO}_{2}$ quickly throughout the TGCs and to imitate wind conditions similar to an open field.

\section{Environmental variables and data collection}

To maintain a target $\left[\mathrm{CO}_{2}\right]$ of $600 \mathrm{ppmV}$ for elevated $\left[\mathrm{CO}_{2}\right], \mathrm{CO}_{2}$ was mixed with air in a mixing cylinder equipped at the air inlet of the TGCs fumigated into the TGCs for $24 \mathrm{~h}$. The fumigating rate of $\mathrm{CO}_{2}$ was computercontrolled with the solenoid valve. The $\left[\mathrm{CO}_{2}\right]$ was monitored (GMT 222, Vaisala, Switzerland) every $5 \mathrm{~s}$ at $1.0 \mathrm{~m}, 11.0$ $\mathrm{m}$ and $22.0 \mathrm{~m}$ distances from the air inlet of the TGCs, and stored in the data logger (CR100,Campbell Scientific, USA) as an average value of $5 \mathrm{~min}$. For ambient $\left[\mathrm{CO}_{2}\right]$, the $\left[\mathrm{CO}_{2}\right]$ was also monitored as was the case for the elevated $\left[\mathrm{CO}_{2}\right]$, though neither was fumigated nor controlled. On average ( \pm s.d.) over the season, the $\left[\mathrm{CO}_{2}\right]$ in elevated and ambient $\left[\mathrm{CO}_{2}\right]$ resulted in $592 \pm 24 \mathrm{ppmV}$ and $386 \pm 15$ ppmV, respectively.

For $\mathrm{T}_{\mathrm{a}}$ control and monitoring, dry-bulb thermo couples were housed in a ventilated radiation shield placed at 20 $\mathrm{cm}$ above plant canopy at distances of $0.6 \mathrm{~m}, 8.0 \mathrm{~m}, 15.5$ $\mathrm{m}$ and $23.0 \mathrm{~m}$ from the air inlet of the TGCs. As with $\left[\mathrm{CO}_{2}\right], \mathrm{T}_{\mathrm{a}}$ was continuously measured every $5 \mathrm{~s}$ and stored in the data logger as an average value of $5 \mathrm{~min}$. Based on these data, the $T_{a}$ at arbitrary distances from the air inlet of the TGCs was calculated by linear interpolation. In the current study, experimental plots were designed at 0.6-1.8 $\mathrm{m}(1.2 \mathrm{~m}$ in the plot center) from the air inlet of the TGCs, 11.4-12.6 m (12.0 m) and at 21.0-22.2 $\mathrm{m}(21.6 \mathrm{~m})$. The mean $\mathrm{T}_{\mathrm{a}}$ from transplanting (4 June) to the full heading stage (18 August) resulted in $26.8^{\circ} \mathrm{C}\left(\sim\right.$ ambient $\left.\mathrm{T}_{\mathrm{a}}\right)$ at 1.2 $\mathrm{m}, 28.1^{\circ} \mathrm{C}\left(1.3^{\circ} \mathrm{C}\right.$ above ambient $)$ at $12.0 \mathrm{~m}$ and $29.8^{\circ} \mathrm{C}$ $\left(3^{\circ} \mathrm{C}\right.$ above ambient) at $21.6 \mathrm{~m}$. Over the season, PAR both inside and outside the TGC was also measured by a quantum sensor (LI-COR, LI-190, Lincoln, NB, USA) every $5 \mathrm{~s}$ and stored in the data logger as an average value of
5 min. The PAR was transmitted through TGC by $91 \%$, and the daily PAR inside the TGC over the season.

\section{Crop culture and measurements}

On 4 June 2005, 3 seedlings per hill of 30-day-old rice (Oryza sativa L., cv. Dongjin1ho) were hand-transplanted in rice soil under either ambient $\left[\mathrm{CO}_{2}\right]$-TGCs or elevated $\left[\mathrm{CO}_{2}\right]$-TGCs. Row and hill space were $30 \mathrm{~cm}$ and $15 \mathrm{~cm}$, respectively $\left(22.2\right.$ hills $\left.\mathrm{m}^{-2}\right)$. In paddy surroundings outside of the TGCs, the seedlings were also transplanted with the same planting density to create canopy conditions. Application rates of nitrogen ( $\mathrm{N}$, as Urea) $-\mathrm{P}_{2} \mathrm{O}_{5}$ (as fused phosphate) $-\mathrm{K}_{2} \mathrm{O}$ (as $\mathrm{KCl}$ ) fertilizers were 11.0-4.5-5.7 $\mathrm{g} \mathrm{m}^{-2} . \mathrm{N}$ was applied as basal dressing 2 days prior to transplanting $(60 \%$ of the total), at mid-tillering (20\%), and at panicle initiation (20\%). Paddies were flooded through most of the growing season, but treated to mid-drainage for 7 days before panicle initiation in mid-July. All other agronomic practices including weeding and pest management were similar to those adopted by local farmers.

At full heading stage (18 August) when plant height fully developed, 5 hills were destructively sampled from each combination treatment plot of $\left[\mathrm{CO}_{2}\right]$ and $\mathrm{T}_{\mathrm{a}}\left(2\left[\mathrm{CO}_{2}\right]\right.$ $\times 3 \mathrm{~T}_{\mathrm{a}}$ factorial plots). At plant sampling, a block of soil $30 \mathrm{~cm}$ wide, $15 \mathrm{~cm}$ long and $15 \mathrm{~cm}$ deep around each individual hill for 2 hills was extracted, whereas only above ground parts were sampled for the rest of the hills. For the former 2 hills, to determine vertical profiles of leaf area, all leaves were cut at intervals of $15 \mathrm{~cm}$ along the stem from ground level to the top, and the leaf area of each layer (i.e. with a $15 \mathrm{~cm}$ layer) was measured separately using leaf area meter (AMM-9, Hayashi Denko Co., Ltd. Japan). The remaining above ground parts of the plant were also cut by the same way, and the dry mas of each layer was determined separately after drying at $80^{\circ} \mathrm{C}$ in a forced air oven for $>72$ hrs. Finally, soil and other extraneous matter were carefully cleansed from the root system under running water and root biomass was determined. For the later 3 hills, all flag leaves were collected, and the individual length, width, area and mass were determined. For all hills (i.e. 5 hills) the plant height and tiller number were also measured. 
Experimental design and statistical analysis

In the basic design, which was a split-plot with the whole plot arranged in randomized complete blocks, two levels of $\left[\mathrm{CO}_{2}\right]$ (ambient or elevated) were the whole plot treatment and three levels of $\mathrm{T}_{\mathrm{a}}$ ( ambient $\mathrm{T}_{\mathrm{a}}, 1.3^{\circ} \mathrm{C}$ and $3.0^{\circ} \mathrm{C}$ above ambient) were the split-plot treatment. There were three blocks, each consisting of an elevated $\left[\mathrm{CO}_{2}\right]-$ and an ambient $\left[\mathrm{CO}_{2}\right]$-TGC located in experimental paddy fields. To test a significant difference among treatments, analysis of variance (ANOVA) in a split-plot design was performed with mean values from each treatment with triplications. Statistical analyses were conducted with a general linear model procedure using a SPSS software package (version 19.0, SPSS Inc., Chicago, IL).

\section{RESULTS}

\section{General features}

Elevated $\left[\mathrm{CO}_{2}\right]$ and $\mathrm{T}_{\mathrm{a}}$, each alone, and their interactive effects were not significant for plant height at full heading stage when it developed fully (Table 1). Elevated $\left[\mathrm{CO}_{2}\right]$ had a minor and insignificant effect on tiller number $(\mathrm{P}=0.156)$, whereas elevated $\mathrm{T}_{\mathrm{a}}$ had a significant positive effect $(\mathrm{P}=0.009)$. Interactive effect between $\left[\mathrm{CO}_{2}\right]$ and $\mathrm{T}_{\mathrm{a}}$ on tiller number was a marginally significant $(\mathrm{P}=0.103)$. As a result, the stimulatory effect of elevated $T_{a}$ was greater in elevated $\left[\mathrm{CO}_{2}\right]$ than in ambient $\left[\mathrm{CO}_{2}\right]$; under $3^{\circ} \mathrm{C}$ warming tiller number increased by $23 \%$ in elevated $\left[\mathrm{CO}_{2}\right]$ and by only $9 \%$ in ambient $\left[\mathrm{CO}_{2}\right]$ (Table 1$)$. Elevated $\left[\mathrm{CO}_{2}\right]$ did not alter root to shoot ratio of rice crops at full heading stage, while elevated $T_{a}$ reduced it $(p=0.076)$; this negative effect of $T_{a}$ was amplified with increasing $T_{a}$ from ambient $\mathrm{T}_{\mathrm{a}}$ to $3.0^{\circ} \mathrm{C}$ above ambient $\mathrm{T}_{\mathrm{a}}$ in both $\left[\mathrm{CO}_{2}\right]$ treatments. However, no $\left[\mathrm{CO}_{2}\right] \times \mathrm{T}_{\mathrm{a}}$ interaction was observed for the root to shoot ratio.

\section{Vertical profiles of leaf area index (LAI)}

Overall, while elevated $T_{a}$ did not alter total LAI at full heading stage, elevated $\left[\mathrm{CO}_{2}\right]$ tended to reduce the LAI $(\mathrm{P}=0.091)$. On average, total LAI was reduced by $6.6 \%$ in elevated $\left[\mathrm{CO}_{2}\right]$ (Fig. 1a). At a given canopy layer (i.e. every $15 \mathrm{~cm}$ layer from ground level to the top), the LAI was affected neither by elevated $\left[\mathrm{CO}_{2}\right](\mathrm{P}=0.211-0.645)$ nor by elevated $\mathrm{T}_{\mathrm{a}}(\mathrm{P}=0.116-0.681)$, allocating the largest LAI in the middle part $(45-75 \mathrm{~cm})$ of the canopy (Fig 1a; Table 2). However, the fraction of LAI distributed in a higher $(75-90 \mathrm{~cm})$ and in a lower layer $(45-60 \mathrm{~cm})$ was strongly affected by elevated $\mathrm{T}_{\mathrm{a}}$, but not by elevated $\left[\mathrm{CO}_{2}\right]$ (Fig. 1a; Table 2). On average, the LAI distributed in the $75-90 \mathrm{~cm}$ (and 45-60 cm) layer of total LAI was 9.4\% (and 35.0\%), 18.8\% (25.9\%) and 18.6\% (29.2\%) in ambient $\mathrm{T}_{\mathrm{a}}, \quad 1.3^{\circ} \mathrm{C}$ and $3.0^{\circ} \mathrm{C}$ above ambient $\mathrm{T}_{\mathrm{a}}$, respectively. Cumulative LAI to a given canopy layer from the top was also unaffected both by elevated $\left[\mathrm{CO}_{2}\right]$ and $\mathrm{T}_{\mathrm{a}}$ (Fig $1 \mathrm{~b}$;

Table 1. Plant height, tiller number and root to shoot ratio (mean \pm standard error of three replicates) at full heading stages of rice crops exposed to either ambient or elevated $\mathrm{CO}_{2}$ with three regimes of air temperature $\left(\mathrm{T}_{\mathrm{a}}\right)$. Analysis of variance (ANOVA) results (P-value only) are shown.

\begin{tabular}{ccccc}
\hline \hline \multicolumn{1}{c}{$\mathrm{CO}_{2}$} & $\mathrm{~T}_{\mathrm{a}}$ & Plant height $(\mathrm{cm})$ & Tillers $\left(\right.$ no. $\left.\mathrm{m}^{-2}\right)$ & Root/shoot ratio \\
\hline Ambient & Ambient $^{*}$ & $88.4 \pm 2.0$ & $266.6 \pm 8.5$ & $0.097 \pm 0.016$ \\
& $+1.3^{\circ} \mathrm{C}$ & $90.3 \pm 8.5$ & $253.7 \pm 15.2$ & $0.103 \pm 0.010$ \\
& $+3.0^{\circ} \mathrm{C}$ & $96.4 \pm 3.2$ & $290.7 \pm 17.7$ & $0.075 \pm 0.001$ \\
Elevated & Ambient & $94.2 \pm 2.3$ & $246.3 \pm 13.0$ & $0.123 \pm 0.026$ \\
& $+1.3^{\circ} \mathrm{C}$ & $100.1 \pm 0.4$ & $287.0 \pm 15.2$ & $0.098 \pm 0.010$ \\
& $+3.0^{\circ} \mathrm{C}$ & $98.3 \pm 2.2$ & $327.7 \pm 9.6$ & $0.081 \pm 0.002$ \\
ANOVA results & & & & \\
$\mathrm{CO}_{2}$ & & 0.366 & 0.156 & 0.586 \\
$\mathrm{~T}_{\mathrm{a}}$ & & 0.223 & 0.009 & 0.076 \\
$\mathrm{CO}_{2} \times \mathrm{T}_{\mathrm{a}}$ & & 0.505 & 0.103 & 0.467 \\
\hline
\end{tabular}

${ }^{*}$ indicates mean ambient $\mathrm{T}_{\mathrm{a}}$ and was a $26.8^{\circ} \mathrm{C}$. 

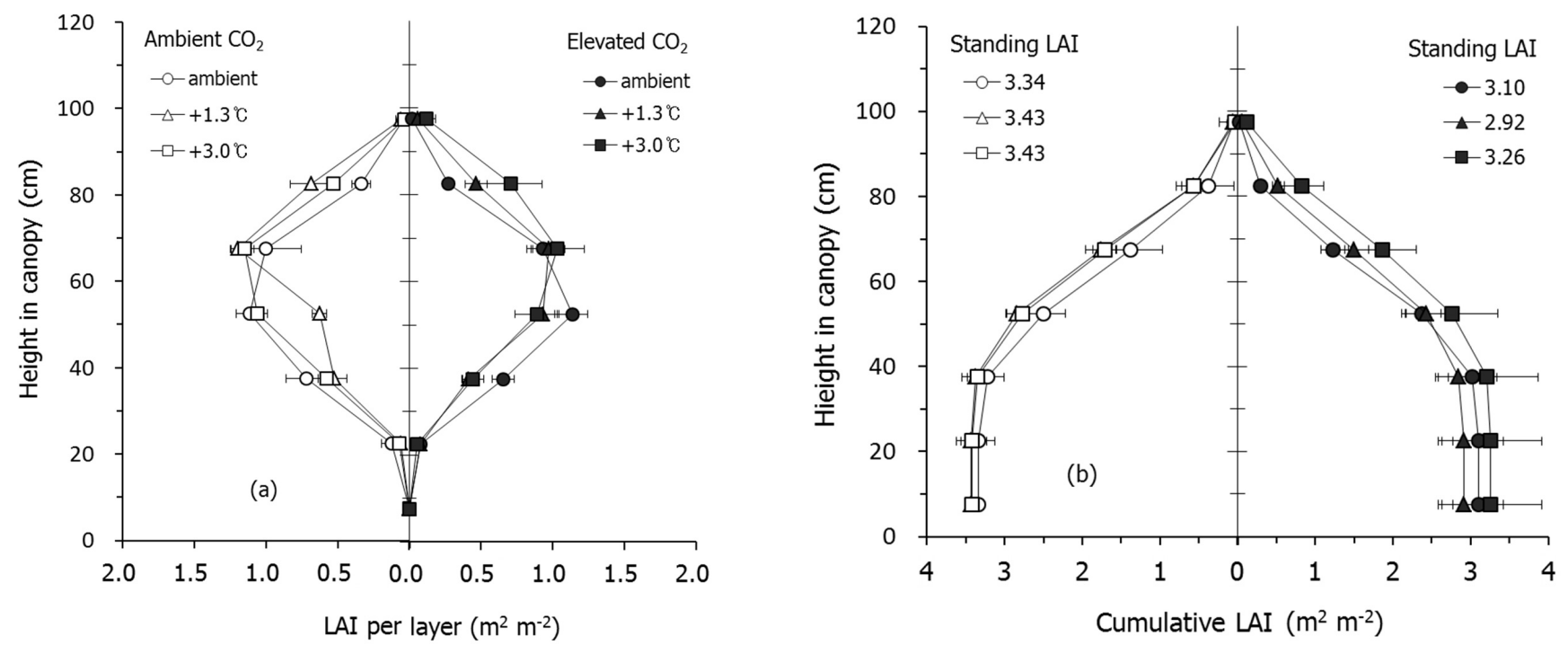

Fig. 1. (a) Vertical profiles of leaf area (expressed by leaf area index, LAI) and (b) cumulative LAI at a given canopy layer within canopy at full heading stage of rice (cv. Dongjin1ho) grown at either elevated or ambient $\left[\mathrm{CO}_{2}\right]$ with three regimes of air temperature [ambient $\mathrm{T}_{\mathrm{a}}\left(26.8^{\circ} \mathrm{C}\right), 1.3^{\circ} \mathrm{C}$ and $3.0^{\circ} \mathrm{C}$ above ambient]. Canopy height was from the ground level. Data are represented as means ( \pm standard error bars) of three replicates. See table 2 for the statistical significance.

Table 2. The results (P-values) of analysis of variance in split-plot design on leaf area (expressed by leaf area index, LAI) in terms of vertical arrangement (LAI), distribution (\%) and cumulative LAI at a given canopy layer at full heading stage of rice grown under either elevated or ambient $\left[\mathrm{CO}_{2}\right]$ (main-plot) with three regimes of air temperature $\left(\mathrm{T}_{\mathrm{a}}\right.$, sub-plot).

\begin{tabular}{|c|c|c|c|c|c|c|c|c|}
\hline \multirow{2}{*}{ Effects } & \multirow{2}{*}{ parameters } & \multicolumn{7}{|c|}{ Height in canopy $(\mathrm{cm})$} \\
\hline & & $>90$ & \multicolumn{2}{|c|}{$75-90(>75)^{\mathrm{a}} 60-75(>c$} & 60) $45-60(>45$ & \multicolumn{2}{|c|}{ 5) 30-45 (> 30) 15-30 (> 15) } & \multirow[t]{2}{*}{$0-15(>0)$} \\
\hline & LAI & & & & & & & \\
\hline $\mathrm{CO}_{2}$ & & 0.464 & 0.645 & 0.386 & 0.390 & 0.210 & 0.544 & - \\
\hline $\mathrm{T}_{\mathrm{a}}$ & & 0.448 & 0.122 & 0.681 & 0.361 & 0.116 & 0.460 & - \\
\hline \multirow[t]{2}{*}{$\mathrm{CO}_{2} \times \mathrm{T}_{\mathrm{a}}$} & & 0.262 & 0.625 & 0.881 & 0.593 & 0.937 & 0.639 & - \\
\hline & LAI distribution (\%) & & & & & & & \\
\hline $\mathrm{CO}_{2}$ & & 0.474 & 0.443 & 0.839 & 0.914 & 0.559 & 0.640 & - \\
\hline $\mathrm{T}_{\mathrm{a}}$ & & 0.324 & 0.015 & 0.289 & 0.001 & 0.122 & 0.436 & - \\
\hline \multirow[t]{2}{*}{$\mathrm{CO}_{2} \times \mathrm{T}_{\mathrm{a}}$} & & 0.213 & 0.389 & 0.887 & 0.026 & 0.939 & 0.628 & - \\
\hline & Cumulative LAI & & & & & & & \\
\hline $\mathrm{CO}_{2}$ & & 0.520 & 0.580 & 0.386 & 0.334 & 0.146 & 0.088 & - \\
\hline $\mathrm{T}_{\mathrm{a}}$ & & 0.473 & 0.155 & 0.333 & 0.717 & 0.899 & 0.919 & - \\
\hline $\mathrm{CO}_{2} \times \mathrm{T}_{\mathrm{a}}$ & & 0.288 & 0.545 & 0.788 & 0.877 & 0.882 & 0.909 & - \\
\hline
\end{tabular}

${ }^{a}$ is only applicable for the cumulative LAI.

Table 2).

\section{Flag leaf morphology}

The length of flag leaf (LFL) decreased by $12.1 \%$ $(\mathrm{P}=0.037)$ in elevated $\left[\mathrm{CO}_{2}\right]$ and significantly increased by
$21.0 \%(\mathrm{p}=0.026)$ in elevated $\mathrm{T}_{\mathrm{a}}\left(+3.0^{\circ} \mathrm{C}\right)$ (Fig 2a). The negative effect of elevated $\left[\mathrm{CO}_{2}\right]$ on LFL was reduced with increasing $\mathrm{T}_{\mathrm{a}}$, though no $\left[\mathrm{CO}_{2}\right] \times \mathrm{T}_{\mathrm{a}}$ interaction was found. Under elevated $\left[\mathrm{CO}_{2}\right]$, the width of flag leaf (WFL) also decreased by $5.0 \%$, whereas it slightly but significantly 

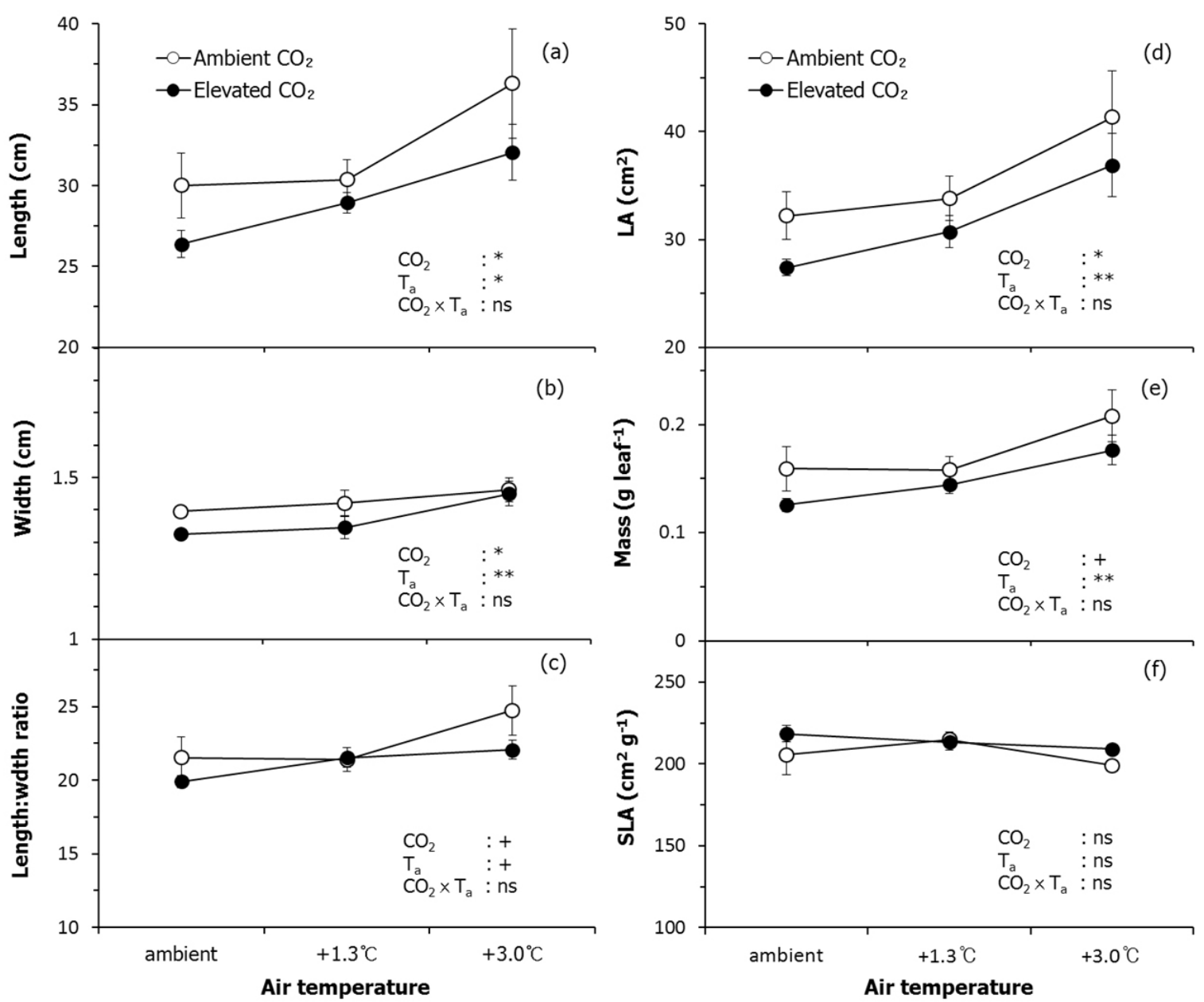

Fig. 2. Morphological traits [(a) length, (b) width, (c) length : width ratio, (d) leaf area, (e) leaf mass and (f) specific leaf area, SLA] of flag leaf of the rice plants grown at either elevated or ambient $\left[\mathrm{CO}_{2}\right]$ with three regimes of air temperature $\left(\mathrm{T}_{\mathrm{a}}\right)$ [ambient $\mathrm{T}_{\mathrm{a}}\left(26.8^{\circ} \mathrm{C}\right), 1.3^{\circ} \mathrm{C}$ and $3.0^{\circ} \mathrm{C}$ above ambient]. Data are represented as means ( \pm standard error bars) of three replicates. ${ }^{* *}, *,+$ and $\mathrm{ns}$ indicate $\mathrm{P}<0.01, \mathrm{P}<0.05, \mathrm{P}<0.1$ and no significance, respectively.

increased (1.9-4.8\%) under elevated $\mathrm{T}_{\mathrm{a}}$ (Fig 2b). Overall, the effect of elevated $\left[\mathrm{CO}_{2}\right]$ and $\mathrm{T}_{\mathrm{a}}$ on WFL was smaller than that on LFL. As a result, the response of length to width $(\mathrm{L}: \mathrm{W})$ ratio in flag leaf to elevated $\left[\mathrm{CO}_{2}\right]$ and $\mathrm{T}_{\mathrm{a}}$ was also smaller compared to that of LFL, and only marginally significant ( $\mathrm{P}=0.083-0.101)$ (Fig. $2 \mathrm{c}$ ); the $\mathrm{L}: \mathrm{W}$ ratio resulted in no change (in elevated $\left[\mathrm{CO}_{2}\right]$ and combined with $1.3-3.0^{\circ} \mathrm{C}$ warming), decrease $7.5 \%$ (in elevated $\left[\mathrm{CO}_{2}\right]$ alone) and increase $15.0 \%$ (in $3.0^{\circ} \mathrm{C}$ warming). The response of leaf area (FLA) of single flag leaf to elevated $\left[\mathrm{CO}_{2}\right]$ and $\mathrm{T}_{\mathrm{a}}$ showed a similar fashion to that of LFL (Fig. $2 \mathrm{~d}$ ), exhibiting a greatest increase by $28.4 \%$ in $3.0^{\circ} \mathrm{C}$ warming $(\mathrm{P}=0.006)$ and decrease by $14.9 \%$ in elevated $\left[\mathrm{CO}_{2}\right]$ alone $(\mathrm{P}=0.017)$. Reflecting this, elevated $\left[\mathrm{CO}_{2}\right]$ resulted in a significant decrease in flag leaf mass (FLM) by $20.9 \%$ $(\mathrm{P}=0.098)$, whereas elevated $\mathrm{T}_{\mathrm{a}}\left(3.0^{\circ} \mathrm{C}\right.$ warming) led to a significant increase by $30.7 \%(\mathrm{P}=0.011)$ (Fig. 2e). However, specific leaf area (SLA; leaf area per unit leaf dry mass) was not altered both at elevated $\left[\mathrm{CO}_{2}\right]$ and $\mathrm{T}_{\mathrm{a}}$ (Fig 2f). Specific leaf mass (SLM; leaf dry mass per unit leaf area, and a reciprocal of the SLA) was also the case that unchanged with elevated $\left[\mathrm{CO}_{2}\right]$ and $\mathrm{T}_{\mathrm{a}}$ (data not shown).

\section{DISCUSSION}

This study was simply designed to evaluate the consequences of global warming with elevated $\left[\mathrm{CO}_{2}\right]$ on key plant morphological parameters of rice crops. Overall, plant 
height, tiller number and root to shoot ratio tended to be less affected by elevating $\left[\mathrm{CO}_{2}\right]$ rather than by elevating $\mathrm{T}_{\mathrm{a}}$ (Table 1). Indeed, earlier studies also showed that elevated $\left[\mathrm{CO}_{2}\right]$ had little affect plant height of inbred japonica rice species (Kim et al., 1996). Recently, however, Yang et al. (2009) reported that elevated $\left[\mathrm{CO}_{2}\right]$ could increase plant height of hybrid rice in China. These divergent results may suggest that plant height of rice crops in response to elevated $\left[\mathrm{CO}_{2}\right]$ could vary depending on their genotypes. On the other hand, higher $\mathrm{T}_{\mathrm{a}}$ can stimulate cell division and expansion in plant organs (Hamamoto et al., 2006), thereby increasing plant height (Oh-e et al., 2007). We also observed a slight increase (but not significant) in plant height by rising $\mathrm{T}_{\mathrm{a}}$; the magnitudes of the increase were by $2.1 \%\left(1.3^{\circ} \mathrm{C}\right.$ above ambient $)$ and $9.0 \%\left(3.0^{\circ} \mathrm{C}\right.$ above ambient $)$ under ambient $\left[\mathrm{CO}_{2}\right]$ and by $13.2 \%$ and $11.2 \%$ under elevated $\left[\mathrm{CO}_{2}\right]$ (Table 1). Taken together, it is therefore possible that ongoing rising $T_{a}$ could have the potential to increase in plant height of rice crops. Considering the plant lodging, this would be of undesirable plant architectures under expected warming in future climate. Alternatively, this can be advantageous for $\mathrm{CO}_{2}$ diffusion inside rice canopy, thereby increasing photosynthesis (Kuroda et al., 1989), unless there is concern about the plant lodging.

In the present study, there was no increase in the tiller number of rice crops at elevated $\left[\mathrm{CO}_{2}\right]$. However, it is well documented that elevated $\left[\mathrm{CO}_{2}\right]$ had a significant positive effect on tiller number of rice (Kim et al., 1996; Jitla et al., 1997; Yang et al., 2009). In particular, the stimulatory effect of elevated $\left[\mathrm{CO}_{2}\right]$ on tiller number was pronounced in vegetative growth stage, while the effect became significantly small in reproductive stage due to the fact that a large portion of tiller produced was expired during reproductive stage (Kim et al., 2003). The latter likely supported our result that at full heading stage tiller number showed the lack of response to elevated $\left[\mathrm{CO}_{2}\right]$. This was probably attributed to the strong carbon $(\mathrm{C})$ and nitrogen $(\mathrm{N})$ sink of the vigorous reproductive tiller, which may have depressed the supply of $\mathrm{C}$ and $\mathrm{N}$ to the smaller tillers (Daepp et al., 2001), eventually leading to the annihilation of the small tillers. Unlike elevated $\left[\mathrm{CO}_{2}\right]$, elevated $\mathrm{T}_{\mathrm{a}}$ had a still significant positive effect on tiller number even at full heading stage $(\mathrm{P}=0.009$; Table 1$)$; the stimulatory effect of $\mathrm{T}_{\mathrm{a}}$ was more pronounced in $3.0^{\circ} \mathrm{C}$ than in $1.3^{\circ} \mathrm{C}$ above ambient, and at elevated $\left[\mathrm{CO}_{2}\right]$ than at ambient $\left[\mathrm{CO}_{2}\right]$, resulting in a marginally significant positive $\left[\mathrm{CO}_{2}\right]$ $\times T_{a}$ interaction $(P=0.103)$. Higher $T_{a}$ was expected to produce more tiller than ambient $\mathrm{T}_{\mathrm{a}}$ during the vegetative growth (Oh-e et al., 2007; Kim et al., 2011). However, the higher- $\mathrm{T}_{\mathrm{a}}$-induced increase in tiller was not always linked to the increase in final tiller number at harvest (Oh-e et al., 2007). Even so, the increased tillers with rising $T_{a}$, irrespective of whether or not they would be productive, may have the potential to change canopy architecture in terms of horizontalspatial distribution of tiller densities.

Under elevated $\left[\mathrm{CO}_{2}\right]$, despite a significant increase in root biomass (data not shown), as has open been reported ((Kim et al., 2003; Ziska and Bunce, 2007; Yang et al., 2007), the root : shoot ratio was not altered in this study. This suggested that elevated $\left[\mathrm{CO}_{2}\right]$ is unlikely to change the balance between above- and below-ground developments of rice cultivar used (i.e. Dongjin1ho) in this study. However, some other reported that elevated $\left[\mathrm{CO}_{2}\right]$ increases root : shoot ratio in rice cultivar IR72 (Baysa et al., 2003) and Akitakomachi (Kim et al., 2003), suggesting that there may be a genotypic variation in root : shoot ratio in response to elevated $\left[\mathrm{CO}_{2}\right]$.

A notable feature of the results was that, despite the reduction in total LAI under elevated $\left[\mathrm{CO}_{2}\right](\mathrm{P}=0.091)$, the vertical profiles of LAI remained unchanged under elevated $\left[\mathrm{CO}_{2}\right]$ and $\mathrm{T}_{\mathrm{a}}$ treatments (Fig. 1a). Early studies have addressed the fact that leaf area or LAI of rice crops grown at elevated $\left[\mathrm{CO}_{2}\right]$ increased during the vegetative stage, but decreased during the grain filling (Kim et al., 2003; Sakai et al., 2006). Our result that total LAI observed at full heading stage reduced with elevated $\left[\mathrm{CO}_{2}\right]$ was in line with previous findings. Taken together, our results suggested that, although elevated $\left[\mathrm{CO}_{2}\right]$ could affect total LAI, it could not lead to a significant alteration of rice canopy structure in terms of at least vertical profiles of the LAI. However, this does not mean that leaf angle would also be unchanged. Assuming that leaf angle is in inverse relation to leaf nitrogen $(\mathrm{N})$ content (Chen et al., 2003), rice crops grown in elevated $\left[\mathrm{CO}_{2}\right]$ will be expected to have more erect leaves than those in ambient $\left[\mathrm{CO}_{2}\right]$ because rice plants showed a significant reduction in leaf 
$\mathrm{N}$ content at elevated $\left[\mathrm{CO}_{2}\right]$ (Kim et al., 2003, 2011; Seneweera et al., 2011; Yang et al., 2007). On the other hand, elevated $T_{a}$ significantly increased the fraction of LAI distributed into the upper layer $(75-90 \mathrm{~cm})$, but decreased that distributed into the lower layer $(45-60 \mathrm{~cm})$ both under ambient and elevated $\left[\mathrm{CO}_{2}\right]$ (Fig. 1a; Table 2). This is most likely associated with the effect of elevated $\mathrm{T}_{\mathrm{a}}$ both on leaf expansion and crop phenology, i.e. (i) an expansion of the leaf area can be greater in elevated $T_{a}$ than in ambient $T_{a}$ (Hamamoto et al., 2006), resulting in more LAI in the upper layer that has a relatively new leaves, (ii) by contrast, the senescence of the leaves in the lower layer can be commenced earlier in elevated $T_{a}$ than in ambient $T_{a}$ due to the hastened crop phenology (Craufurd and Wheeler, 2009), resulting in a less LAI in the lower canopy layer at warmer $T_{a}$.

The most striking result was that most of the parameters related to flag leaf morphology is negated with elevated $\left[\mathrm{CO}_{2}\right]$ (Fig. 2). There were about 12\%, 5\%, 7.5\%, 15\% and $21 \%$ decreases in LFL, WFL, L:W ratio, FLA and FLM, respectively, in elevated $\left[\mathrm{CO}_{2}\right]$ in comparison with ambient $\left[\mathrm{CO}_{2}\right]$. This result is likely to partly reflect advanced crop phenology under elevated $\left[\mathrm{CO}_{2}\right]$. In the present study, under elevated $\left[\mathrm{CO}_{2}\right]$, the timing of the flowering was earlier 2 days at current ambient $\mathrm{T}_{\mathrm{a}}$ (14 August in ambient $\left[\mathrm{CO}_{2}\right]$ vs 12 August in elevated $\left.\left[\mathrm{CO}_{2}\right]\right)$, and 3 days at two levels of warmer $T_{a}$ (11 August vs 8 August). Such a phenology shift was also the case at warmer $T_{a}$ under current ambient $\left[\mathrm{CO}_{2}\right]$, and has been reported for many crops species grown under elevated $\left[\mathrm{CO}_{2}\right]$ and/or $\mathrm{T}_{\mathrm{a}}(\mathrm{Kim}$ et al., 1996; Craufurd and Wheeler, 2009). Under elevated $\left[\mathrm{CO}_{2}\right]$, earlier flowering indicates a shortening the duration of crop growth from transplanting to the flowering. This could have the potential to reduce in the period of development of the flag leaves, leading to shorter and narrower flag leaves, and eventually to less FLA. However, our result showed that $\mathrm{T}_{\mathrm{a}}$ warming could offset to some extent of the negative effects of elevated $\left[\mathrm{CO}_{2}\right]$ on flag leaves. As discussed earlier, this was most likely attributed to the enhanced leaf expansion with elevated $\mathrm{T}_{\mathrm{a}}$ (Hamamoto et al., 2006).

The flag leaves of rice plant play a critical role in plant or canopy photosynthesis during the ripening phase, occupying of about $19 \%$ of total leaf area at heading (Yoshida et al., 1972), and contributing about $45 \%$ of grain yield (Aboukhalifa et al., 2008). Despite such an importance of the flag leaf in rice yield processes (Peng et al., 2008), there is no report addressing the flag leaf morphology of rice plants under changes in $\left[\mathrm{CO}_{2}\right]$ and climate. This is the first study, of which we are aware, that has investigated flag leaf morphology of field-grown rice under elevated $\left[\mathrm{CO}_{2}\right]$ and $\mathrm{T}_{\mathrm{a}}$, though we did not determine grain yield. It appears, however, that it is difficult to assess how the modified flag leaf morphology affects grain yield. This is because the yield processes will likely to be further complicated by the fact that elevated $\left[\mathrm{CO}_{2}\right]$ and $\mathrm{T}_{\mathrm{a}}$ also can modify the rates of net photosynthesis (Ainsworth and Long, 2005) and the life span of leaves (Seneweera et al., 2011), as well as the flag leaf morphology. Therefore, it is needed to further study in integration of whole-plant and flag leaf morphology responses and models, in order to better understand of rice yield processes under changes in $\left[\mathrm{CO}_{2}\right]$ and climate.

In conclusion, the data presented here suggests that plant height of rice (cv, Dongjin1ho) among the components of plant architecture is not affected by elevating $\left[\mathrm{CO}_{2}\right]$, but will be more or less increased by temperature warming (1.3-3.0 ${ }^{\circ} \mathrm{C}$ above ambient). In addition, the temperature warming could have the potential to alter in canopy structure via modifying both the horizontal-spatial distribution of rice tillers and the vertical profiles of LAI. More importantly, the results of this study clearly demonstrate that most of the parameters with respect to flag leaf morphology is negated with elevated $\left[\mathrm{CO}_{2}\right]$, and that the negative effect of elevated $\left[\mathrm{CO}_{2}\right]$ can be offset to some extent by temperature warming.

\section{ACKNOWLEDGEMENT}

This study was financially supported by research fund of Chonnam National University.

\section{REFERENCES}

Abou-khalifa, A. A. B, A. N. Misra, A. E. A. K. M. Salem. 2008. Effect of leaf cutting on physiological traits and yield 
of two rice cultivars. African J. Plant Sci. 2 : 147-150.

Ainsworth, E. A., S. P. Long. 2005. What have we learned from 15 years of free-air $\mathrm{CO}_{2}$ enrichment (FACE)? A meta-analytic review of the responses of photosynthesis, canopy properties and plant production to rising $\mathrm{CO}_{2}$. New Phytol. 165 : 351-372.

Ariyaratna, M., I. Takamura, K. Kato. 2011. Plant architecture and its responses to high planting density and low fertilizer of reduced culm number mutants in rice (Oryza sativa L.). J. Plant Breeding Crop Sci. 3 : 114-119.

Baysa, M. C., D. C. Tremmel, J. F. Reynolds, G. C. Rivero, R. A. Tabbada. 2003. The interactive effects of elevated $\mathrm{CO}_{2}$, temperature and $\mathrm{N}$ supply on $\mathrm{N}$ concentration and allocation in rice (Oryza sativa L.). Philipp. Agric. Sci. 86 : 117-122.

Chen, Y., E. H. Murchie, S. Hubbart, P. Horton, S. Peng. 2003. Effects of season-dependent irradiance levels and nitrogen- deficiency on photosynthesis and photoinhibition in field- grown rice (Oryza sativa). Physiol. Plantarum. 117 : 343-351.

Craufurd, P. Q., T. R. Wheeler. 2009. Climate change and the flowering time of annual crops. J. Expt. Bot. 60 : 2529-2539.

Evans, L. T., H. M. Rawson. 1970. Photosynthesis and respiration by the flag leaf and components of the ear during grain development in wheat. Aust. J. Bio. Sci. 23 : 245-254.

Hamamoto, H., M. Kimura, I. Yamaguchi. 2006. High resolution analysis of plant organ growth using non-contact inkjet marking. Environ. Exp. Bot. 57 : 62-69.

Horie, T., H. Nakagawa, J. Nakano, K. Hamotani, H. Y. Kim. 1995. Temperature gradient chamber for research on global environment change. III. A system designed for rice in Kyoto, Japan. Plant Cell Environ. 18, 1064-1069.

Jitla, D. S., G. S. Roger, S. P. Seneweera, A. S. Bsara, R. J. Oldfield and J. P. Conroy. 1997. Accelerated early growth of rice at elevated $\mathrm{CO}_{2}-$ Is it related to developmental changes in shoot apex? Plant Physoil. $115: 15-22$.

Kim, H. Y., T. Horie, H. Nakagawa, K. Wada. 1996. Effects of elevated $\mathrm{CO}_{2}$ and high temperature on growth and yield of rice: I. The effect on development, dry matter production and some growth characteristics of Akihikari rice. Jpn. J. Crop Sci. 65 : 634-643.

Kim, H. Y., M. Lieffering, K. Kobayashi, M. Okada, S. Miura. 2003. Seasonal changes in the effects of elevated $\mathrm{CO}_{2}$ on rice at three levels of nitrogen supply: a free air $\mathrm{CO}_{2}$ enrichment (FACE) experiment. Global Change Biol. 9 : 826-837.

Kim, H. Y., V. Tang, J. B. Seo, K. Y. Kim, J. S. Baik, K. S. Min. 2004. A system designed for controlling both $\mathrm{CO}_{2}$ concentration and air temperature in paddies. Korean J. Crop Sci. 51(suppl. 2) : 148-149.

Kim, H. Y., S. S. Lim, J. H. Kwak, D. S. Lee, S. M. Lee, H. M. Ro, W. J. Choi. 2011. Dry matter and nitrogen accumulation and partitioning in rice (Oryza sativa L.) exposed to experimental warming with elevated $\mathrm{CO}_{2}$. Plant Soil. 342 : 59-71.

Khush, G. S. 2001. Green revolution: the way forward. Nat. Rev. Genet. 2 : 815-822.

Kuroda, E., T. Ookawa, K. Ishihara. 1989. Analysis on difference of dry matter production between rice cultivars with different plant height in relation to gas diffusion inside stands. Jpn. J. Crop Sci. 58 : 374-382.

Oh-e, I., K. Saitoh and T. Kuroda. 2007. Effects of high temperature on growth, yield and dry-matter production of rice grown in the paddy field. Plant Pro. Sci. 10 : 412-422.

Okada, M., T. Hamasaki, R. Sameshima. 2000. Pre-air-conditioned temperature gradient chambers for research on temperature stress in plants. Biotronics. $29: 43-55$.

Daepp, M., J. Nösberger and A. Lüscher. 2001. Nitrogen fertilization and developmental stage alter the response of Lolium perenne to elevated $\mathrm{CO}_{2}$. New Phytol. 150 : 347-358.

Peng, S., G. S. Khush, P. Virk, Q. Tang, Y. Zou. 2008. Progress in ideotype breeding to increase rice yield potential. Field Crops Res. 108 : 32-38.

Sakai, H., H. Hasegawa, K. Kobayashi. 2006. Enhancement of rice canopy carbon gain by elevated $\mathrm{CO}_{2}$ is sensitive to growth stage and leaf nitrogen concentration. New Phytol. $170: 321-331$.

Seneweera, S., A. Makino, N. Hirotsu, R. Norton, Y. Suzuki. 2011. New insight into photosynthetic acclimation to elevated $\mathrm{CO}_{2}$; The role of leaf nitrogen and ribulose1,5-biphosphate carboxylase/oxygenage content in rice leaves. Environ. Exp. Bot. 71 : 128-136.

Yang, L., J. Hung, H. Yang, G. Dong, H. Liu, G. Liu, J. Zhu, Y. Wang. 2007. Seasonal changes in the effects in the free-air $\mathrm{CO}_{2}$ enrichment (FACE) on nitrogen (N) uptake and utilization of rice at three levels of $\mathrm{N}$ fertilization. Field Crops Res. 100 : 189-199.

Yang, L., H. Liu, Y. Wang, J. Zhu, J. Huang, G. Liu, G. Dong and Y. Wang. 2009. Yield formation of $\mathrm{CO}_{2}$-enriched inter-subspecific hybrid rice cultivar Liangyoupeijiu under fully open-air field condition in a warm sub-tropical climate. Agri. Ecosyst. Environ. 129 : 193-200.

Yoshida, S., J. H. Cock, F. T. Parao. 1972. Physiological aspects of high yields. In: Rice breeding. Philipines (Manila), International Rice Research Institute. pp. 455-514.

Zhu, C. W., J. G. Zhu, G. Liu, Q. Cheng, Z. B. Xie, J. Pang, Z. Z. Feng, H. Y. Tang, L. Wang. 2008. Elevated $\mathrm{CO}_{2}$ concentration enhances the role of the ear to the flag leaf in determining grain yield of wheat. Photosynthetica. 46 : 318-320.

Ziska, L. H., J. M. Bunce. 2007. Predicting the impacts of changing $\mathrm{CO}_{2}$ on crop yields: some thoughts on food. New Phytol. 175 : 607-618. 